ступеня кандидата медичних наук за спеціальністю 14.01 .02 «Внутрішні хвороби». - ДВНЗ «Ужгородський національний університет» МОН України, м. Ужгород, 2017. 264 с.

14. Rayner C.K., Samson M., Jones K.L. Relationships of upper gastrointestinal motor and sensory function with glycemic control. Diabetes Care. 2001. Vol. 24. № 2. P. 371-381.

DOI https://doi.org/10.30525/978-9934-26-038-4-34

\title{
ОСОБЛИВОСТІ ЛІКУВАННЯ ДІТЕЙ МОЛОДШОГО ВІКУ 3 ДЕФЕКТАМИ ЗУБНИХ РЯДІВ ФРОНТАЛЬНОЇ ДІЛЯНКИ ПОСДНАНИХ $З$ ТРАНСВЕРЗАЛЬНИМИ АНОМАЛІЯМИ
}

\author{
Савонік С. М. \\ магістр медицини, \\ асистент кафедри ортопедичної стоматології та ортодонтії \\ ПВНЗ «Київський медичний університет» \\ м. Київ, Украӥна
}

Вступ: Дефекти зубних рядів фронтальної ділянки на сьогоднішній день $\epsilon$ досить поширеними серед дитячого населення, особливо молодшого віку, які в більшості своїх випадків виникають в наслідок нелікованого карієсу та його ускладнень. Тому для дітей є досить важливим питання відновлення функціональних та естетичних вимог, що в подальшому запобігає утворенню вторинних зубо-щелепних деформацій, які в такому віці виникають досить швидко.

Мета роботи: Підвищення ефективності ортопедичного та ортодонтичного лікування дітей молодшого віку, шляхом розробки та впровадження раціональних апаратів для заміщення дефектів зубних рядів фронтальної ділянки.

Матеріали та методи: Нами було проведено лікування 22 дітей віком від 4-5 років, тобто з тимчасовим періодом прикусу з дефектами зубних рядів фронтальної ділянки різної протяжності. В залежності від вибору методу заміщення дефекту зубного ряду та конструктивних елементів апаратів пацієнти були розподілені на 2 клінічні групи: основну та порівняння. До основної групи увійшло 10 дітей та групи порівняння склало 12 осіб. Усім пацієнтам була проведена повна санація порожнини рота, визначення гігієнічного статусу та навчання навичкам гігієни порожнини рота. Основну групу пацієнтів лікували за допомогою незнімного апарата-протеза на верхню щелепу власної конструкції 
(патент України на корисну модель № 145538 від 28.12.2020), групу порівняння лікували знімними ортодонтичними апаратами - протезами. Результати проведеного лікування оцінювали за допомогою аналізу вимірювання контрольно-діагностичних моделей щелеп за 3.І. Долгополовою на початку лікування та через 6 місяців.

Результати дослідження: Результати вимірювання контрольно діагностичних моделей щелеп до лікування в основній групі: в області між III-III зубами - звуження зубних дуг на 2,8 80,7 , через 6 місяців $+0,2 \pm 0,04$; в ділянці IV - IV до лікування - звуження на $3,0 \pm 0,7$, після 6 місяців лікування - +0,3 $\pm 0,03$; в області між $\mathrm{V}-\mathrm{V}$ зубами до лікування $-3,4 \pm 0,5$, через 6 місяців - $+0,2 \pm 0,05$. У дітей, які входили до групи порівняння дані показники становили: у ділянці до лікуввання III - III - звуження зубнх дуг на 2,2 $\pm 0,6$, через 6 місяців $--1,5 \pm 0,4$ між IV - IV зубами верхньої щелепи до лікування - звуження на $2,9 \pm 0,8$, через 6 місяців лікування - $-1,9 \pm 0,5$; в ділянці між $\mathrm{V}-\mathrm{V}$ зубами до лікування даний показник становив - $-3,3 \pm 0,6$ та після - звуження на $-2,2 \pm 0,6$ мм. Позитивна динаміка у проведенні ортопедичного лікування дітей із корекцією розмірів верхньої щелепи у трансверзальній площині пояснюється тим, що апарат - протез власної конструкції працює більш прогнозовано, за рахунок постійного знаходження в порожнині рота та збільшення часу його активної дії в порожнині рота по відношенню до знімних апаратів.

Висновок: Оптимізація комплексного лікування дефектів зубних рядів фронтальної ділянки у дітей молодшого віку використовуючи незнімний апарат протез власної конструкції значно покращує результати лікування, зокрема заміщення дефекту зубного ряду, відновлення функціональних та естетичних вимог, а також розширення зубних дуг в трансверзальній площині, що $є$ не менш важливо при лікуванні аномалій зубних дуг. 